\title{
Microbial synthesis of poly- $\gamma$-glutamic acid: current progress, challenges, and future perspectives
}

\author{
Zhiting Luo ${ }^{1 \dagger}$, Yuan Guo ${ }^{2 \dagger}$, Jidong Liu ${ }^{1}$, Hua Qiu', Mouming Zhao ${ }^{1}$, Wei Zou ${ }^{3 *}$ and Shubo Li $^{1^{*}}$ (e)
}

\begin{abstract}
Poly-y-glutamic acid ( $\gamma$-PGA) is a naturally occurring biopolymer made from repeating units of L-glutamic acid, D-glutamic acid, or both. Since some bacteria are capable of vigorous $\gamma$-PGA biosynthesis from renewable biomass, $\gamma$-PGA is considered a promising bio-based chemical and is already widely used in the food, medical, and wastewater industries due to its biodegradable, non-toxic, and non-immunogenic properties. In this review, we consider the properties, biosynthetic pathway, production strategies, and applications of $Y$-PGA. Microbial biosynthesis of $Y$-PGA and the molecular mechanisms regulating production are covered in particular detail. Genetic engineering and optimization of the growth medium, process control, and downstream processing have proved to be effective strategies for lowering the cost of production, as well as manipulating the molecular mass and conformational/enantiomeric properties that facilitate screening of competitive $\gamma$-PGA producers. Finally, future prospects of microbial $\gamma$-PGA production are discussed in light of recent progress, challenges, and trends in this field.
\end{abstract}

Keywords: Poly- $\gamma$-glutamic acid, Metabolic regulation, Microbial fermentation, Strain development, Process optimization, Industrial applications

\section{Background}

Poly- $\gamma$-glutamic acid ( $\gamma$-PGA) is an unusual anionic homopolyamide made from $\mathrm{D}$-and L-glutamic acid units connected through amide linkages between $\alpha$-amino and $\gamma$-carboxylic acid groups [1] (Additional file 1: Fig. S1). Based on the glutamate residues present, $\gamma$-PGA may be classified as $\gamma$-L-PGA (only L-glutamic acid residues), $\gamma$-DPGA (only D-glutamic acid residues), and $\gamma$-LD-PGA (both $\mathrm{L}$ - and D-glutamic acid residues). At present, there exist four methods for $\gamma$-PGA production: chemical synthesis, peptide synthesis, biotransformation, and microbial fermentation [2]. Compared with other methods, microbial fermentation is the most cost-effective and has numerous advantages, including inexpensive raw materials, minimal

\footnotetext{
*Correspondence: weizou@suse.edu.cn; Shubo1207@gxu.edu.cn

'Zhiting Luo and Yuan Guo contributed equally to this work

${ }^{1}$ College of Light Industry and Food Engineering, Guangxi University, Nanning 530004, China

${ }^{3}$ College of Bioengineering, Sichuan University of Science

and Engineering, Zigong 643000, Sichuan, China

Full list of author information is available at the end of the article
}

environmental pollution, high natural product purity, and mild reaction conditions. Initially discovered in 1937 by Bruckner and co-workers as part of the capsule of Bacillus anthracis, $\gamma$-PGA has since been found in species from all three domains of life (archaea, bacteria, and eukaryotes) $[3,4]$. Most commercial $\gamma$-PGA is currently produced via microbial fermentation from biomass.

Unlike most proteinaceous materials, $\gamma$-PGA is synthesized in a ribosome-independent manner; thus, substances that inhibit protein translation (such as chloramphenicol) have no effect on the production of $\gamma$-PGA [5]. Furthermore, due to the $\gamma$-linkage of its component glutamate residues, $\gamma$-PGA is resistant to proteases that cleave $\alpha$-amino linkages [6]. More importantly, as a biodegradable, water-soluble, edible, and non-toxic biopolymer, $\gamma$-PGA and its derivatives can be used safely in a wide range of applications including as thickeners, humectants, bitterness-relieving agents, cryoprotectants, sustained release materials, drug carriers, heavy metal absorbers, and animal feed additives. 
Although the microbial production of $\gamma$-PGA is well established, the cost of production, including the cost of substrates as well as process costs, remains high. Most recent research on $\gamma$-PGA production is therefore focused on optimizing growth conditions to increase yield, manipulate enantiomeric composition, and alter the molecular mass. Surprisingly, only a small number of mini reviews on the biosynthesis and applications of $\gamma$-PGA have been published to date [1, 6-9]. Therefore, in this review, we have gathered together our accumulated knowledge on the bacterial physiology and catabolism of $\gamma$-PGA, and outlined the existing biological $\gamma$-PGA production processes, placing particular emphasis on improving bacterial $\gamma$-PGA fermentation.

\section{Overview of $\boldsymbol{Y}$-PGA}

\section{Structural characteristics of $\gamma$-PGA}

Generally, $\gamma$-PGA adopts five conformations; $\alpha$-helix, $\beta$-sheet, helix-to-random coil transition, random coil, and enveloped aggregate. The conformation can be changed by altering environmental conditions such as $\mathrm{pH}$, polymer concentration, and ionic strength [10]. For example, $\gamma$-PGA adopts a largely $\alpha$-helical conformation at $\mathrm{pH} 7$, but predominantly $\beta$-sheet-based conformation at higher $\mathrm{pH}$ [11]. The enantiomeric composition also varies and can be manipulated through the extraction process after fermentation. For example, $\gamma$-PGA containing only $\mathrm{L}$ or $D$ enantiomers is soluble in ethanol, whereas $\gamma$-PGA containing equimolar amounts of $\mathrm{L}$ and $\mathrm{D}$ precipitates in ethanol [6]. Manipulating the enantiomeric composition of $\gamma$-PGA to alter its properties is therefore possible [12].

The molecular mass of $\gamma$-PGA can also influence its properties and efficacy for specific applications. Microbialderived $\gamma$-PGA generally has a relatively high molecular weight (Mw $\sim 10^{5}-8 \times 10^{6} \mathrm{Da}$ ), which can limit industrial applications due to high viscosity, unmanageable rheology, and difficult modification [1]. Therefore, polymers with different molecular weights may be required for different purposes, and controlling the molecular weight is of fundamental and practical importance for commercial development. Recently, medium composition, alkaline hydrolysis, ultrasonic degradation, and microbial or enzymatic degradation have all been used to alter the molecular weight of $\gamma$-PGA [1]. Of these, ultrasonic irradiation provides an interesting alternative to enzymatic hydrolysis and has been proposed to reduce both the molecular weight and polydispersity of $\gamma$-PGA without disturbing the chemical composition of the polymer [13].

\section{Physiological function of $\gamma$-PGA}

As present, the physiological function of $\gamma$-PGA is not completely understood and is believed to depend on the environment in which the organism inhabits, and whether it is bound to peptidoglycan [7]. Peptidoglycanbound $\gamma$-PGA may protect bacterial cells against phage infections and prevent antibodies from gaining access to the bacterium [14]. Staphylococcus epidermidis synthesizes surface-associated $\gamma$-PGA to protect against antimicrobial peptides and escape phagocytosis, which contributes to virulence [15]. More importantly, $\gamma$-PGA can be released into the environment to sequester toxic metal ions, decrease salt concentration [4], provide a carbon source [15], and protect against adverse conditions [16]. $\gamma$-PGA can also improve the formation of biofilms and assist absorption of essential nutrients from the environment [17].

\section{Microbial biosynthesis of $\boldsymbol{\gamma}$-PGA}

Recently, information about the genes and enzymes involved in $\gamma$-PGA synthesis has been reported and has contributed to the design of production systems $[6,8]$. As shown in Fig. 1, the proposed microbial biosynthetic pathway of $\gamma$-PGA involves L-glutamic acid units derived exogenously or endogenously (using $\alpha$-ketoglutaric as a direct precursor) [18]. Biosynthesis can be divided into four distinct stages; racemization, polymerization, regulation, and degradation.

\section{$\gamma$-PGA racemization}

Generally, $\gamma$-PGA is synthesized from D- or L-glutamate alone, or from both $\mathrm{L}$ and $\mathrm{D}$ enantiomers together [19, 20]. However, to incorporate D-glutamate into the growing L-chain, L-glutamate (exogenous or endogenous) is first converted into D-glutamate by a racemization reaction. In B. subtilis, two homologs of the glutamate racemase gene ( $r a c \mathrm{E} / g l r$ and $y r p C$ ) have been identified, and $g l r$ is essential for converting L-glutamate into D-glutamate for the synthesis of $\gamma$-PGA [21]. Interestingly, RacE and yrpC are cytosolic enzymes with a high selectivity for glutamate and a preference for the $\mathrm{L}$-form, but neither are responsible for the synthesis of $\gamma$-PGA [22]. The functions of these enzymes remains unknown $[22,23]$.

\section{Y-PGA polymerization}

As shown in Fig. 2, polyglutamate synthase (pgs) is encoded by four genes (pgsB, C, A, and E) and their homologs in Bacillus species are $y w s \mathrm{C}, y w t \mathrm{AB}$, and capBCA $[1,24]$. Recently, pgsBCA was identified as the sole machinery responsible for polymerizing $\gamma$-PGA at the active site of the synthase complex (PgsBCA) in an ATP-dependent reaction [25]. PgsB and PgsC form the main parts of the catalytic site, whereas PgsA removes the elongated chain from the active site, which is necessary for addition of the next monomer and transporting $\gamma$-PGA through the compact cell membrane [8]. The role of pgsE in the production of $\gamma$-PGA was found to be 


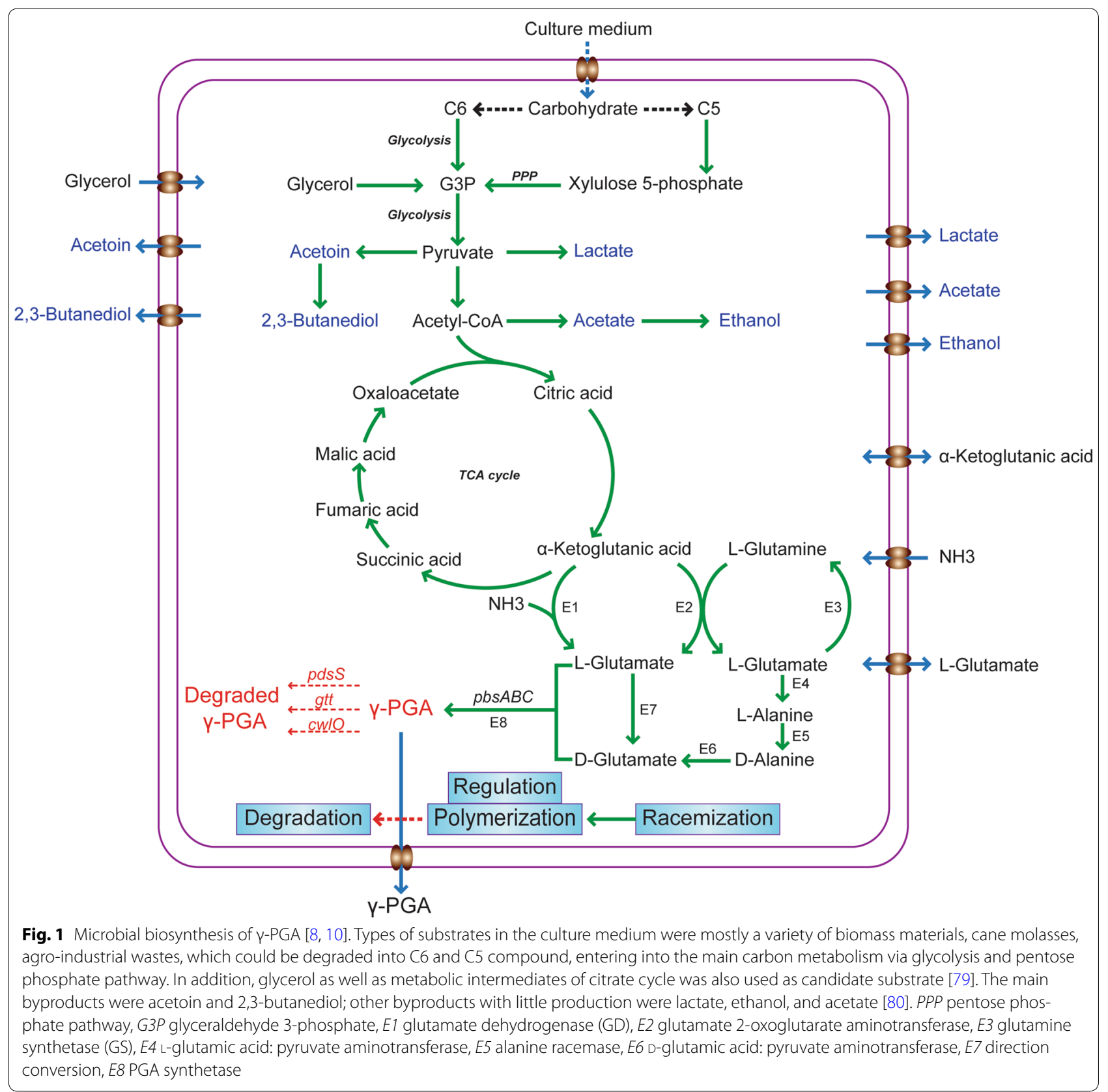

dispensable, and high concentrations of $\mathrm{pgsB}$, pgsC, and pgsA were able to form $\gamma$-PGA in the absence of pgsE [26]. However, other researchers found that pgsE was essential for $\gamma$-PGA production in the presence of $\mathrm{Zn}^{2+}$ in B. subtilis [27]. This may be because the unique membrane-bound PgsBCA complex is highly unstable and hydrophobic, which could affect its isolation [7].

\section{$Y$-PGA regulation}

$\gamma$-PGA synthesis is regulated by two signal transduction systems: the ComP-ComA regulator, and the two-part
DegS-DegU, DegQ, and SwrA system [28]. The role of DegQ has been thoroughly investigated, and alteration of $\operatorname{deg} \mathrm{Q}$ prevents the synthesis of $\gamma$-PGA and effectively downregulates the production of degradation enzymes [29]. However, the relationship between SwrA and DegU remains poorly understood. Osera et al. discovered that the presence of both SwrA and phosphorylated DegU (DegU-P) could fully activate the pgs operon for $\gamma$-PGA production, but the effect of either gene on both pgs transcription and $\gamma$-PGA production was negligible [30]. In contrast, Ohsawa et al. showed that a high level of 


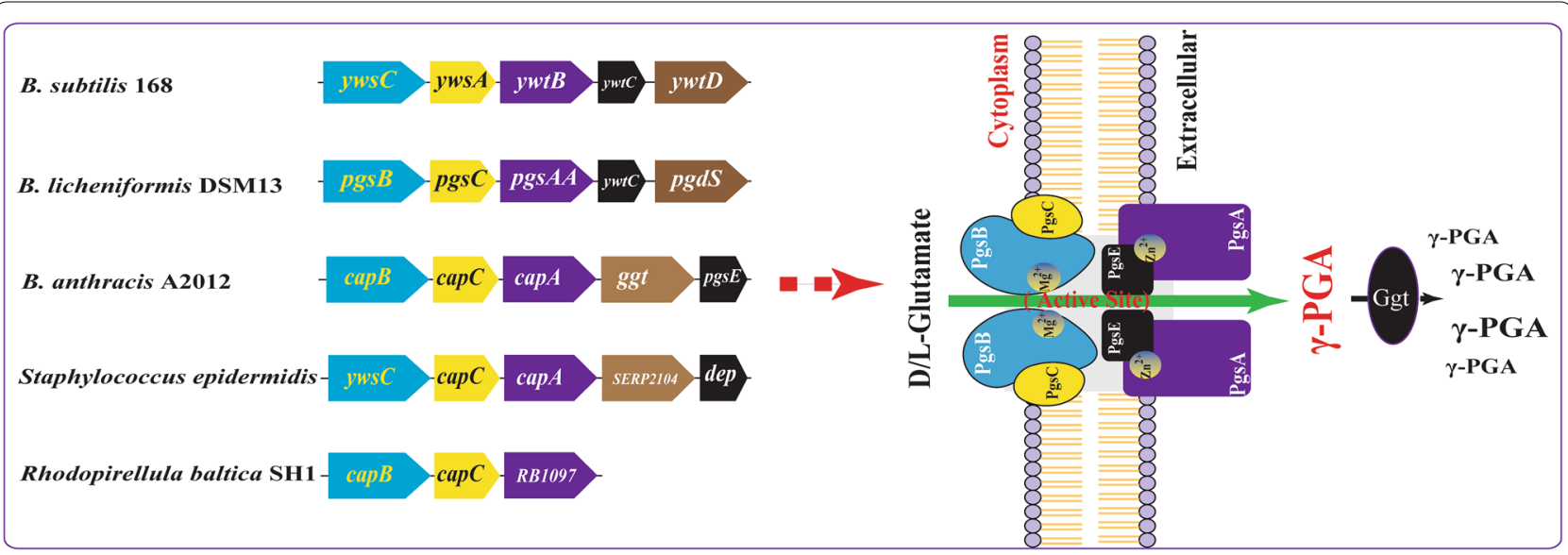

Fig. 2 Arrangement of genes encoding $\gamma-P G A$ synthetase and $\gamma$-PGA peptidase complexes in various species. All components of $\gamma$-PGA synthetase are essentially membrane associated) [8]

DegU-P could directly activate pgs expression for $\gamma$-PGA production in place of swrA [31]. Overall, DegSU, DegQ, and ComPA appear to be involved in transcriptional regulation in response to quorum sensing, osmolarity, and phase variation signals, while SwrA appears to act at a post-transcriptional level [32].

\section{Y-PGA degradation}

There are two enzymes capable of degrading $\gamma$-PGA in Bacilli: endo- $\gamma$-glutamyl peptidase and exo- $\gamma$-glutamyl peptidase [33]. Endo- $\gamma$-glutamyl peptidase can be secreted into the medium by $B$. subtilis and B. licheniformis, where it is able to cleave high molecular weight $\gamma$-PGA into fragments of $1000 \mathrm{Da}$ to $20 \mathrm{kDa}$, which decreases dispersity as a function of depolymerization time [22, 34, 35]. In B. subtilis, the genes encoding endo$\gamma$-glutamyl peptidase $(y w t \mathrm{D}, d e p$, or $p g d \mathrm{~S})$ are located directly downstream of, and in the same orientation as, the pgsBCA operon (Fig. 2), and the protein product includes a hydrophobic cluster $\left({ }^{10} \mathrm{~F}-\mathrm{L}-\mathrm{L}-\mathrm{V}-\mathrm{A}-\mathrm{V}-\mathrm{I}-\mathrm{I}-\mathrm{C}-\right.$ F-L-V-P-I- $\left.\mathrm{M}^{24}\right)$ and a cleavage site $\left({ }^{30} \mathrm{~A}-\mathrm{E}-\mathrm{A}^{32}\right)$ proximal to the $\mathrm{N}$-terminus, indicating that the mature enzyme is secreted into the medium [36].

Exo- $\gamma$-glutamyl peptidase (Ggt) is a key enzyme in glutathione metabolism, and catalyzes the formation of $\gamma$-glutamic acid di- and tripeptides in vitro, but does not appear to be involved in $\gamma$-PGA synthesis in vivo $[36,37]$. For example, ggt (or capD) was required for covalently anchoring the $\gamma$-PGA capsule to the peptidoglycan layer of the cell surface in B. anthracis, but not for $\gamma$-PGA synthesis [26]. As a member of the $\gamma$-glutamyl transpeptidase (GGT) family, CapD is able to cleave and subsequently transfer $\gamma$-PGA to an acceptor molecule or $\mathrm{H}_{2} \mathrm{O}$, resulting in transpeptidation or hydrolysis, respectively [38]. GTTs display exohydrolase activity toward $\gamma$-PGA, releasing glutamate as a source of carbon and nitrogen [39]. In $B$. subtilis, ggt and capD are located on the chromosome distant from the pgsBCA cluster and expressed during the stationary phase under the control of the ComQXPA quorum-sensing system, but are located on a plasmid directly downstream from the pgsBCA cluster in $B$. anthracis [40].

As mentioned above, $\gamma$-PGA can be anchored to the bacterial surface or released into the medium, and CapD catalyzes the anchorage of $\gamma$-PGA to the peptidoglycan, whereas PgsS catalyzes its release. Therefore, inhibiting or knocking down $\gamma$-PGA hydrolase can result in the production of high molecular weight $\gamma$-PGA [41]. Indeed, B. subtilis strains deficient in exopeptidase are unable to cleave $\gamma$-PGA into fragments smaller than $10^{5} \mathrm{kDa}$, and they sporulate earlier than wild-type strains [22].

\section{Fermentation engineering for $\boldsymbol{\gamma}$-PGA production}

At present, $\gamma$-PGA can be synthesized by Bacillus species, Fusobacterium nucleatum, and some archaea and eukaryotes [3], but Bacillus species are used most widely to study biological $\gamma$-PGA production. Bacteria are either L-glutamate-dependent (B. subtilis CGMCC 0833 [42], B. licheniformis P-104 [43]) or non-L-glutamatedependent (e.g. B. subtilis $\mathrm{C} 1$ [44] and B. amyloliquefaciens LL3 [45]) producers of $\gamma$-PGA. For L-glutamic acid-dependent bacteria, PGA yield can be enhanced by increasing the L-glutamate concentration, but this increases the cost of production significantly [8]. In contrast, due to the low cost of production and simple fermentation process, L-glutamate-independent producers are more desirable for industrial $\gamma$-PGA production, but are limited by their lower $\gamma$-PGA productivity [45]. 
Therefore, the cost of production (including both productivity and substrates) is a major limitation for microbial $\gamma$-PGA production.

To this end, most research on $\gamma$-PGA fermentation has focused on optimizing growth conditions to improve $\gamma$-PGA yield, alter the enantiomeric composition, and manipulate the molecular mass of $\gamma$-PGA [25]. Additionally, genetic engineering of non-glutamate-dependent producers such as B. amyloliquefaciens [46], B. subtilis [47], and E. coli [48] has also been used to increase $\gamma$-PGA production.

\section{Strain screening and improvement}

Numerous Bacillus species have been established as $\gamma$-PGA producers, and native strains can produce more than $20 \mathrm{~g} / \mathrm{L}$ of $\gamma$-PGA in fermentation processes. As shown in Table 1 , the top ten strains are all rod-shaped, Gram-positive, endospore-forming members of the order Bacillales. Most $\gamma$-PGA producers can therefore be divided into two groups: Group I = Bacillus species; Group II = other bacteria.

Bacillus subtilis is a Gram-positive, endospore-forming, rod-shaped bacteria that has generally been recognized as having a safe (GRAS) status and can therefore be used to produce enzymes such as alpha amylase and proteases that are used in the food and medicine industries. Isolation of $B$. subtilis strains with excellent $\gamma$-PGA production abilities has been achieved due to its ubiquitous and sporulating nature. As shown in Table 1, many B. subtilis strains have been widely used for producing $\gamma$-PGA, and B. subtilis CGMCC 1250 produces $101.1 \mathrm{~g} / \mathrm{L}$ $\gamma$-PGA, demonstrating the potential this organism has for $\gamma$-PGA production [49]. More importantly, simple enrichment and screening procedures without mutagenesis or genetic manipulation identified native strains that can produce more than $20 \mathrm{~g} / \mathrm{L}$ of $\gamma$-PGA [50]. Bacillus licheniformis, Gram-positive, endospore-forming bacterium, shares many similarities with $B$. subtilis, and this non-pathogenic organism has also been exploited for the production of $\gamma$-PGA.

Other than the two Bacillus species discussed above, Bacillus methylotrophicus SK19.001 should also be noted, because it yields a high level of $\gamma$-PGA with an ultrahigh molecular weight [51]. Other species such as $B$. anthracis and Bacillus thuringiensis also have the capacity for $\gamma$-PGA production [52], but these organisms attach $\gamma$-PGA to peptidoglycan instead of secreting it into the medium, making the recovery and purification procedure

Table 1 Strains, fermentation media, and control methods of the ten highest-yielding Y-GPA fermentation processes

\begin{tabular}{|c|c|c|c|c|c|}
\hline Starting sources & $\begin{array}{l}\text { Isolation or improvement } \\
\text { methods }\end{array}$ & $\begin{array}{l}\text { Fermentation medium } \\
\text { components }\end{array}$ & $\begin{array}{l}\text { Bioreactor and process } \\
\text { control }^{\mathrm{a}}\end{array}$ & Yield (g/L) & Ref. \\
\hline B. subtilis ZJU-7 & $\begin{array}{l}\text { Isolated from fermented bean } \\
\text { curd }\end{array}$ & $\begin{array}{l}\text { Glucose, L-glutamate, yeast } \\
\text { extract, } \mathrm{NaCl}, \mathrm{CaCl}_{2}, \mathrm{MgSO}_{4} \\
\mathrm{MnSO}_{4}\end{array}$ & $\begin{array}{c}\text { 10-L bioreactor, } 300-800 \mathrm{rpm} \\
\text { with } 1.5 \mathrm{vvm}, \mathrm{pH} 6.5,37^{\circ} \mathrm{C}\end{array}$ & 101.1 & {$[49]$} \\
\hline B. subtilis NX-2 & Using co-fermentation strategy & $\begin{array}{l}\text { Glutamate, }(\mathrm{NH} 4)_{2} \mathrm{SO}_{4}, \mathrm{~K}_{2} \mathrm{HPO}_{4 \prime} \\
\mathrm{MgSO}_{4}, \mathrm{MnSO}_{4}, \text { and hydrolysis } \\
\text { of rice straw }\end{array}$ & $\begin{array}{l}\text { 7.5-L bioreactor, } 400 \mathrm{rpm} \text { with } \\
1.2 \mathrm{vvm} \text {, initial } \mathrm{pH} 7.0,32^{\circ} \mathrm{C}\end{array}$ & 73.0 & {$[50]$} \\
\hline B. subtilis NX-2 & Isolated from soil samples & $\begin{array}{l}\text { Glucose, glutamate, }\left(\mathrm{NH}_{4}\right)_{2} \mathrm{SO}_{4} \\
\mathrm{~K}_{2} \mathrm{HPO}_{4}, \mathrm{MgSO}_{4}, \mathrm{MnSO}_{4}\end{array}$ & $\begin{array}{l}\text { 7.5-L APFB for immobilized } \\
\text { fermentation, } 32^{\circ} \mathrm{C}, \mathrm{pH} 7.0\end{array}$ & 71.21 & {$[42]$} \\
\hline B. subtilis MJ80 & Isolated from soil samples & $\begin{array}{l}\text { Glutamic acid, starch, urea, citric } \\
\text { acid, glycerol, } \mathrm{NaCl}, \mathrm{K}_{2} \mathrm{HPO}_{4 \prime} \\
\mathrm{MgSO}_{4}, \mathrm{MnSO}_{4}\end{array}$ & $\begin{array}{l}\text { 3-L fermenter, } 37^{\circ} \mathrm{C}, 150 \mathrm{rpm} \\
\text { with } 1 \mathrm{vvm} \text {, initial pH } 7.0\end{array}$ & 68.7 & {$[56]$} \\
\hline B. subtilis NX-2 & Isolated from soil samples & $\begin{array}{l}\text { Cane molasses and monoso- } \\
\text { dium glutamate waste liquor }\end{array}$ & $\begin{array}{l}\text { 7.5-L bioreactor, } 400 \text { rpm at } \\
1.2 \mathrm{vvm}, 32^{\circ} \mathrm{C}, \mathrm{pH} 7.0\end{array}$ & 52.1 & {$[55]$} \\
\hline B. licheniformis P-104 & $\begin{array}{l}\text { Isolated from Chinese soybean } \\
\text { paste }\end{array}$ & $\begin{array}{l}\text { Glucose, sodium glutamate, } \\
\text { sodium citrate, }(\mathrm{NH} 4)_{2} \mathrm{SO}_{4} \\
\mathrm{MnSO}_{4}, \mathrm{MgSO}_{4}, \mathrm{~K}_{2} \mathrm{HPO}_{4}\end{array}$ & 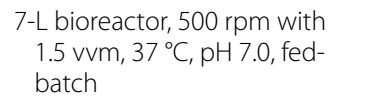 & 41.6 & [43] \\
\hline B. licheniformis NCIM 2324 & $\begin{array}{l}\text { Addition of metabolic precur- } \\
\text { sors }\end{array}$ & $\begin{array}{l}\text { Glycerol, L-glutamic acid, } \\
\text { citric acid, }(\mathrm{NH} 4)_{2} \mathrm{SO}_{4}, \mathrm{~K}_{2} \mathrm{HPO}_{4} \\
\mathrm{MgSO}_{4}, \mathrm{MnSO}_{4}\end{array}$ & $\begin{array}{l}\text { 250-mL flask, } 200 \mathrm{rpm}, 37^{\circ} \mathrm{C} \text {, } \\
\text { initial pH } 6.5\end{array}$ & 35.75 & [81] \\
\hline B. methylotrophicus SK19.001 & Isolated from soil samples & $\begin{array}{l}\text { Glucose, yeast extracts, } \mathrm{MgSO}_{4 \prime} \\
\mathrm{K}_{2} \mathrm{HPO}_{4}, \mathrm{MnSO}_{4}\end{array}$ & $\begin{array}{l}250 \mathrm{~mL} \text { flask, } 200 \mathrm{rpm} \text {, initial pH } \\
\quad 7.2,37^{\circ} \mathrm{C}\end{array}$ & 35.34 & {$[51]$} \\
\hline B. subtillis HB-1 & Isolated from soil samples & $\begin{array}{l}\text { Glutamate, yeast extract, } \mathrm{NaCl} \text {, } \\
\mathrm{MgSO}_{4} \text {, xylose, or corncob } \\
\text { fibers hydrolysate }\end{array}$ & $\begin{array}{l}\text { 10-L bioreactor, } 500 \mathrm{rpm}, 37^{\circ} \mathrm{C} \text {, } \\
\text { initial pH 6.5, fed-batch }\end{array}$ & 28.15 & {$[82]$} \\
\hline B. licheniformis TISTR 1010 & $\begin{array}{l}\text { Using different feeding strate- } \\
\text { gies }\end{array}$ & $\begin{array}{l}\text { Glucose, citric acid, } \mathrm{NH}_{4} \mathrm{Cl}, \\
\mathrm{K}_{2} \mathrm{HPO}_{4}, \mathrm{MgSO}_{4}, \mathrm{CaCl}_{2}, \mathrm{MnSO}_{4} \\
\mathrm{NaCl} \text {, Tween-80, }\end{array}$ & $\begin{array}{l}\text { 7-L fermenter, } 300 \mathrm{rpm} \text { and } \\
1 \mathrm{vvm} \text {, initial } \mathrm{pH} 7.4,37^{\circ} \mathrm{C}\end{array}$ & 27.5 & [83] \\
\hline
\end{tabular}

\footnotetext{
${ }^{a} v v m$ volumes of air per volume of broth, APFB aerobic plant fibrous-bed bioreactor
} 
more difficult. More importantly, the production of $\gamma$-PGA using $B$. anthracis is not viable owing to its toxicity [53].

\section{Biosynthesis of $\gamma$-PGA in different hosts}

With the development of metabolic engineering, homologous hosts have been engineered for $\gamma$-PGA production (Table 2). However, while much laborious manipulation has been attempted on various strains, only a low $\gamma$-PGA yield has been achieved. Therefore, only a limited number of strains are considered useful for industrial $\gamma$-PGA bioproduction, and the selection of a good strain for further improvement is the crucial starting element.

Expression of $\gamma$-PGA-producing genes in heterologous hosts has been attempted (Table 2). Escherichia coli is the most commonly used host for $\gamma$-PGA biosynthesis, and the $\gamma$-PGA synthase genes pgsBCA and racE from $B$. licheniformis NK-03 and B. amyloliquefaciens LL3 were, respectively, cloned and co-expressed in $E$. coli JM109 to evaluate $\gamma$-PGA production [48]. The engineered strain could produce $\gamma$-PGA from both glucose and L-glutamate, and co-expression of the $\mathrm{racE}$ gene further increased the production of $\gamma$-PGA to $0.65 \mathrm{~g} / \mathrm{L}$. Another similar study was carried out using Corynebacterium glutamicum as the host, clone, and expression of the $\gamma$-PGA synthase genes pgsBCA from Bacillus subtilis TKPG011. The production of $\gamma$-PGA reached $18 \mathrm{~g} / \mathrm{L}$ when the combinant was cultured with the limitation of biotin [54]. Those studies suggested that the selection of the appropriate $\gamma$-PGA-producing genes from the appropriate species may be one of the key issues. In any case, the final yield of $\gamma$-PGA is still far below that produced by native strains.

\section{Optimization of the growth medium}

As shown in Fig. 1, pyruvate is the precursor for $\gamma$-GPA in many bacterial species, and its secretion is tightly associated with cell growth. Therefore, suitable culture media could support vigorous cell growth and hence generate enough precursor for $\gamma$-GPA synthesis.

Other than glucose which is the most successful carbon substrate for $\gamma$-GPA production from a variety of biomass materials, cane molasses, xylose, agro-industrial wastes, rapeseed meal, soybean residue, fructose,corncob fibers, hydrolysate, and crude glycerol have also been tested (Tables 1,2). Although some of these substrates resulted in a modest $\gamma$-GPA yield, a wider substrate spectrum should be investigated. Cane molasses were shown to be a suitable fermentable substrate for $\gamma$-PGA production, and statistical optimization of medium components resulted in the production of $52.1 \mathrm{~g} / \mathrm{L}$ of $\gamma$-PGA from cane molasses, without optimizing the fermentation process [55]. Cane molasses may provide an even higher $\gamma$-GPA yield following optimization of the strain and fermentation process.

Table 2 Exemplar engineering of homologous and heterogeneous hosts

\begin{tabular}{|c|c|c|c|c|}
\hline Strains & Engineering methods & Fermentation medium & $\begin{array}{l}\text { Pro- } \\
\text { duc- } \\
\text { tion } \\
(\mathrm{g} / \mathrm{L})\end{array}$ & Ref. \\
\hline $\begin{array}{l}\text { B. licheniformis } \\
\text { WX-02 }\end{array}$ & Expression of glr gene encoding glutamate racemase & $\begin{array}{l}\text { Glucose, L-glutamic acid, sodium citrate, } \mathrm{NH}_{4} \mathrm{Cl}, \mathrm{MgSO}_{4} \text {, } \\
\mathrm{K}_{2} \mathrm{HPO}_{4}, \mathrm{CaCl}_{2}, \mathrm{ZnSO}_{4}, \mathrm{MnSO}_{4}\end{array}$ & 14.38 & [75] \\
\hline $\begin{array}{l}\text { B. amyloliquefa- } \\
\text { ciens LL3 }\end{array}$ & Double-deletion of genes pgdS and $c w / O$ & Sucrose, $\left(\mathrm{NH}_{4}\right)_{2} \mathrm{SO}_{4}, \mathrm{MgSO}_{4}, \mathrm{KH}_{2} \mathrm{PO}_{4}, \mathrm{~K}_{2} \mathrm{HPO}_{4}$ & 7.12 & [84] \\
\hline $\begin{array}{l}\text { B. amyloliquefa- } \\
\text { ciens LL3 }\end{array}$ & Deletion of genes (rocR, rocG, gudB, odhA) & Sucrose, $\left(\mathrm{NH}_{4}\right)_{2} \mathrm{SO}_{4}, \mathrm{MgSO}_{4}, \mathrm{KH}_{2} \mathrm{PO}_{4}, \mathrm{~K}_{2} \mathrm{HPO}_{4}$ & 5.68 & [85] \\
\hline $\begin{array}{l}\text { B. subtilis } \\
\text { ISW1214 }\end{array}$ & Bearing the plasmid-borne PGA synthetic system & Sucrose, $\mathrm{NaCl}, \mathrm{MgSO}_{4}, \mathrm{KH}_{2} \mathrm{PO}_{4}, \mathrm{NaHPO}_{4}$, xylose & 9.0 & [47] \\
\hline E. coli BL21 & Cloning and overexpressing $\gamma$-PGA biosynthesis genes & Glucose, yeast extract, L-glutamic acid, $\left(\mathrm{NH}_{4}\right)_{2} \mathrm{SO}_{4}$ & 3.7 & [76] \\
\hline E. coli JM 109 & Co-expressing $\gamma$-PGA synthetase and glutamate racemase & LB medium supplemented with L-glutamate or glucose & 0.65 & [48] \\
\hline $\begin{array}{l}\text { B. amyloliquefa- } \\
\text { ciens }\end{array}$ & $\begin{array}{l}\text { Deletions of genes (epsA-O, sac, Ips, pta, pgdS, cwlO, luxS, } \\
\text { and rocG gene, expression of synthetic small regulatory } \\
\text { RNAs which repressed the rocG and glnA gene }\end{array}$ & Sucrose, $\left(\mathrm{NH}_{4}\right)_{2} \mathrm{SO}_{4}, \mathrm{MgSO}_{4}, \mathrm{KH}_{2} \mathrm{PO}_{4}, \mathrm{~K}_{2} \mathrm{HPO}_{4}$ & 20.3 & [86] \\
\hline B. subtilis PB5249 & Knockout of genes (pgdS and ggt) & $\begin{array}{l}\text { L-glutamic acid, citric acid, glucose, } \mathrm{NH}_{4} \mathrm{Cl}_{1} \mathrm{~K}_{2} \mathrm{HPO}_{4 \prime} \\
\mathrm{MgSO}_{4} \cdot 7 \mathrm{H}_{2} \mathrm{O}, \mathrm{FeCl}_{3} \cdot 6 \mathrm{H}_{2} \mathrm{O}, \mathrm{CaCl}_{2} \cdot 2 \mathrm{H}_{2} \mathrm{O}, \mathrm{MnSO}_{4} \cdot \mathrm{H}_{2} \mathrm{O}, \mathrm{pH} \\
\quad 6.5\end{array}$ & 40 & [87] \\
\hline $\begin{array}{l}\text { Bacillus licheni- } \\
\text { formis WX-02 }\end{array}$ & Enhanced expression of pgdS gene & $\begin{array}{l}\text { Glucose, sodium glutamate, sodium citrate, } \mathrm{NH}_{4} \mathrm{Cl}, \mathrm{MgSO}_{4} \text {, } \\
\mathrm{K}_{2} \mathrm{HPO}_{4}, \mathrm{CaCl}_{2}, \mathrm{ZnSO}_{4}, \mathrm{MnSO}_{4}\end{array}$ & 20.16 & [88] \\
\hline $\begin{array}{l}\text { Corynebacterium } \\
\text { glutamicum }\end{array}$ & Cloning and expressing $\mathrm{Y}$-PGA biosynthesis genes & $\begin{array}{l}\text { Glucose, }\left(\mathrm{NH}_{4}\right)_{2} \mathrm{SO}_{4}, \mathrm{KH}_{2} \mathrm{PO}_{4}, \mathrm{MgSO}_{4} \cdot 7 \mathrm{H}_{2} \mathrm{O}, \mathrm{FeSO}_{4} \cdot 7 \mathrm{H}_{2} \mathrm{O} \\
\mathrm{MnSO}_{4} \cdot 4 \mathrm{H}_{2} \mathrm{O} \text {, soy protein hydrolysate, thiamine hydro- } \\
\text { chloride, } \mathrm{CaCO}_{3}\end{array}$ & 18 & [54] \\
\hline
\end{tabular}


Additionally, much work has been carried out on the nutritional requirements for cell growth to improve $\gamma$-PGA productivity and modify the $\mathrm{D} / \mathrm{L}$ composition of the polymer. For an exogenous glutamate-independent producer, yeast extract proved to be an excellent nitrogen source for bacterial cell growth and $\gamma$-PGA production, but the high cost is a barrier to commercial production [51]. Therefore, attempts have been made to reduce the dosage or replace it with other media supplements such as $\left(\mathrm{NH}_{4}\right)_{2} \mathrm{SO}_{4}$ or $\mathrm{NH}_{4} \mathrm{Cl}$ [56] (Table 1). As well as carbon and nitrogen sources, inorganic salts can affect the production, productivity, and quality of $\gamma$-PGA. $\mathrm{Mn}^{2+}$ in particular can improve cell growth, prolong cell viability, and assist the utilization of different carbon sources, as well as significantly alter the stereochemical and enantiomeric composition of $\gamma$-PGA, and increase $\gamma$-PGA production $[1,19]$.

\section{Process control}

Efficient and effective control of fermentation depends on an understanding of the key biological and chemical parameters [57], and dissolved oxygen and culture $\mathrm{pH}$ are fundamental parameters that need careful control.

Oxygen is essential in aerobic fermentation and affects cell growth, carbon source utilization, biosynthesis of products, and $\mathrm{NAD}(\mathrm{P}) \mathrm{H}$ recycling [58]. Various strategies have been deployed to maintain oxygen supply, including the separated or combined use of oxygen-enriched air, modified impeller design, and addition of other oxygen vectors. However, for production of highly viscous biopolymers such as $\gamma$-PGA, it might be more economical and effective to replace gaseous oxygen with another molecular electron acceptor (Table 3). For example, the effects of different oxygen vectors on the synthesis and molecular weight of $\gamma$-PGA were investigated in a B. subtilis batch fermentation process, and $0.3 \% n$-heptane increased to $39.4 \mathrm{~g} / \mathrm{L}$ and molecular weight $19.0 \times 10^{5} \mathrm{Da}$ [59].

Culture $\mathrm{pH}$ is another important environmental factor in $\gamma$-PGA fermentation [60]. A pH of 6.5 supported rapid cell growth and high $\gamma$-PGA production in B. licheniformis ATCC 9945A [58], whereas the highest biomass and $\gamma$-PGA yield were achieved at $\mathrm{pH} 7$ in B. subtilis IFO 3335 [61]. However, the optimal $\mathrm{pH}$ for glutamate utilization has never been taken into consideration, even though the glutamate transport system is $\mathrm{pH}$ sensitive and is a key factor in $\gamma$-PGA fermentation. Therefore, to further increase the utilization of glutamate and enhance the production of $\gamma$-PGA, a two-stage $\mathrm{pH}$-shift control strategy was proposed and developed, in which $\mathrm{pH}$ was maintained at 7 for the first $24 \mathrm{~h}$ to obtain the maximum biomass, and then shifted to 6.5 to maximize glutamate utilization and $\gamma$-PGA production. As a result, glutamate utilization increased from 24.3 to $29.5 \mathrm{~g} / \mathrm{L}$, and consequently the yield of $\gamma$-PGA increased from 22.2 to $27.7 \mathrm{~g} / \mathrm{L}$ [62].

In industrial fermentation, the choice of reactor operation mode may be vital for achieving optimal process design. A series of operation modes should be tested at small scale, such as batch, fed-batch, continuous culture, cell recycling, and cell immobilization, all of which may have their own advantages and disadvantages. For example, continuous culture can be operated at a steady state with continuous feeding, which can enhance productivity and/or lower labor intensity, but a high yield may be difficult to achieve. For $\gamma$-PGA production, batch and fed-batch are the most common fermentation strategies and, overall, the batch mode has tended to achieve a higher product yield and productivity and is the most promising method for industrial-scale $\gamma$-PGA fermentation (Table 3).

To avoid the addition of exogenous L-glutamic acid, symbiotic fermentation was also proposed and developed, in which the L-glutamate-dependent $B$. subtilis was co-cultured with Corynebacterium glutamicum using glucose and sucrose as a mixed carbon source. Thus, integrated bioprocesses have advantages that included shortening the fermentation time and reducing the production cost, and produced $\gamma$-PGA with an average molecular mass of $1.24 \times 10^{6} \mathrm{Da}$ [63].

\section{Product recovery}

During microbial fermentation, downstream processing is always a key issue for improving process economy. As discussed above, $\gamma$-PGA fermentation is influenced by various nutritional and environmental parameters, and the effects of these variables on product recovery should be assessed. For example, excessive use of complex raw materials will pose difficulties for product isolation.

There exist three fundamentally different approaches to recovering $\gamma$-PGA from the culture broth: precipitation by complex formation, precipitation by reducing water solubility, and filtration [8]. In all cases, the first step is to remove the biomass through centrifugation or filtration with a $0.45 \mu \mathrm{m}$ filter [64]. For complex formation, $\gamma$-PGA can be precipitated using $\mathrm{Cu}^{2+}, \mathrm{Al}^{3+}, \mathrm{Cr}^{3+}$, and $\mathrm{Fe}^{3+}$, and $\mathrm{Cu}^{2+}$ is the most efficient metal ion for selectively precipitating $\gamma$-PGA, even at a low concentration [16]. The resultant precipitate is re-dissolved by adding $1.5 \mathrm{M} \mathrm{HCl}$ and cleaved into monomers and oligomers. Alternatively, $\gamma$-PGA can be precipitated by reducing water solubility, following the addition of ethanol to the supernatant or filtrate and then re-dissolving in distilled water [64]. Compared with complex formation, reducing water solubility is less selective and can result in co-precipitation of proteins and polysaccharides [65]. Finally, due to the 
Table 3 Application of different strategies for improving Y-PGA production

\begin{tabular}{|c|c|c|c|}
\hline Starting sources & Fermentation strategies & Main results & \\
\hline B. licheniformis NCIM 2324 & Optimization via one factor at a time & $\gamma$-PGA production increased from 5.27 to $26.12 \mathrm{~g} / \mathrm{L}$ & \\
\hline B. subtilis CGMCC 0833 & Applying pH-shift control strategy & $\begin{array}{l}\text { Glutamate utilization increased from } 24.3 \text { to } 29.5 \mathrm{~g} / \mathrm{L} ; \gamma-P G A \\
\text { production increased from } 22.2 \text { to } 27.7 \mathrm{~g} / \mathrm{L}\end{array}$ & \\
\hline B. subtilis NX-2 & Using a two-stage strategy for agitation speed control & $\begin{array}{l}\text { The concentration of } \mathrm{Y} \text {-PGA reached } 40.5 \mathrm{~g} / \mathrm{L} \text { with increases } \\
\text { of } 17.7 \%\end{array}$ & \\
\hline B. subtilis NX-2 & Adding different oxygen vectors & $\begin{array}{l}\text { The concentration of } \mathrm{Y}-\mathrm{PGA} \text { reached } 39.4 \mathrm{~g} / \mathrm{L} \text { with increase } \\
\text { of } 25.1 \%\end{array}$ & \\
\hline B. subtilis BL53 & Adding some precursors & The production of $\gamma-P G A$ increased to $25.2 \mathrm{~g} / \mathrm{L}$ & \\
\hline B. subtilis C10 & Addition of organic acid & The concentration of $\mathrm{Y}$-PGA increased from 17.3 to $27.7 \mathrm{~g} / \mathrm{L}$ & \\
\hline B. licheniformis NCIM 2324 & Addition of metabolic precursors & The concentration of Y-PGA reached 35.75 from $26.12 \mathrm{~g} / \mathrm{L}$ & {$[8$} \\
\hline B. licheniformis TISTR 1010 & Using different feeding strategies & $\begin{array}{l}\text { The } \gamma \text {-PGA concentration reached } 27.5 \mathrm{~g} / \mathrm{L} \text { with increase of } \\
\text { fivefold }\end{array}$ & \\
\hline B. subtilis NX-2 & Using co-fermentation strategy & $\begin{array}{l}\text { The production and productivity of } \gamma-P G A \text { reached } 73.0 \mathrm{~g} / \mathrm{L} \\
\text { and } 0.81 \mathrm{~g} / \mathrm{L} / \mathrm{h} \text {, respectively }\end{array}$ & \\
\hline B. subtilis CCTCC M 2012347 & Solid-state fermentation & $\begin{array}{l}\text { Using soybean residue and cane molasses to produce } \\
103.5 \mathrm{~g} / \mathrm{kg} \text { of } \mathrm{Y}-\mathrm{PGA} \text { at } 24 \mathrm{~h} \text { under non-sterilized condi- } \\
\text { tion }\end{array}$ & \\
\hline B. amyloliquefaciens C1 & Solid-state fermentation & Producing $0.0437 \mathrm{~g} \gamma-P G A$ per gram of substrates at $48 \mathrm{~h}$ & \\
\hline B. subtilis GXA-28 & Addition of $\mathrm{KCl}$ & The $\gamma$-PGA yield increased from 18.36 to $25.62 \mathrm{~g} / \mathrm{L}$ by $39.5 \%$ & {$[9$} \\
\hline B. licheniformis & Heat stress and alkaline stress treatment & $\begin{array}{l}\text { The maximum } y \text {-PGA yield reached } 29.34 \mathrm{~g} / \mathrm{L}, 185 \% \text { higher } \\
\text { than the control }\end{array}$ & \\
\hline B. licheniformis WX-02 & Alkaline $\mathrm{pH}$ stress treatment & $\begin{array}{l}\text { The maximum } \gamma \text {-PGA yield reached } 36.26 \mathrm{~g} / \mathrm{L} \text { in the } 50 \mathrm{~L} \\
\text { bioreactor, increased by } 79 \% \text { compared with the control }\end{array}$ & \\
\hline B. subtilis NX-2 & Adding hydrogen peroxide & $\begin{array}{l}\text { The maximum concentration of } 33.9 \mathrm{~g} / \mathrm{L} \gamma-\mathrm{PGA} \text { was } \\
\text { obtained by adding } 100 \mu \mathrm{M} \mathrm{H} \mathrm{H}_{2} \mathrm{O}_{2} \text { to the medium after } \\
24 \mathrm{~h} \text {. This concentration was } 20.6 \% \text { higher than that of } \\
\text { the control }\end{array}$ & \\
\hline
\end{tabular}

large differences in molecule size between high molecular weight $\gamma$-PGA and all other constituents of the culture broth, a series of filtration and buffer exchange steps can be applied to effectively separate $\gamma$-PGA [66]. For example, alcohol precipitation was the widely used method for the recovery of $\gamma$-PGA from cell-free broth, in which the $\gamma$-PGA recovery, concentration factor, and concentration of concentrate could reach about $80 \%, 0.2$, and $110 \mathrm{~g} / \mathrm{L}$, respectively, after acidification ( $\mathrm{pH} 3.0)$ and ultrafiltration [64].

\section{Applications of $\boldsymbol{Y - P G A}$}

Due to being water soluble, biodegradable, edible, and non-toxic, $\gamma$-PGA and its derivatives have been applied in a broad range of industrial fields, including food, cosmetics, agriculture, medicine, and bioremediation (Table 4).

\section{Food industry}

$\gamma$-PGA is used in the food industry, specifically in naturally occurring mucilage of natto (fermented soybeans), but also as a food supplement, osteoporosis-preventing agent, texture enhancer, cryoprotectant, and oil-reducing agent (Table 4). As a cryoprotectant, $\gamma$-PGA enhances the viability of probiotic bacteria during freeze-drying, and $\gamma$-PGA was found to protect Lactobacillus paracasei more effectively than sucrose, trehalose, or sorbitol $[11,67]$. More importantly, as a food supplement, $\gamma$-PGA could effectively increase the bioavailability of calcium by increasing its solubility and intestinal absorption, which decreased bone loss in humans [68].

\section{Medicine}

As shown in Table 2, $\gamma$-PGA and its derivatives have been exploited as metal chelators and drug carriers, and used in tissue engineering and as a biological adhesive in medicine. As a drug delivery agent, the molecular mass of $\gamma$-PGA was the decisive factor determining the drug delivery properties, including controlling the rate of drug release. For example, a $\gamma$-PGA molecular weight of $\sim 3-6 \times 10^{4}$ Da was used to produce paclitaxel poliglumex (a conjugate of $\gamma$-PGA and paclitaxel), and this significantly improved both the safety and efficiency of the drug (compared with standard paclitaxel) by enhancing its pharmacokinetic profile and water solubility. Furthermore, this improved tumor selectivity via enhanced accumulation and retention in tumor tissue [69]. 
Table 4 Applications of $\boldsymbol{\gamma}$-PGA and its derivatives

\begin{tabular}{|c|c|c|c|}
\hline Field & Applications & Details & Ref. \\
\hline \multirow[t]{6}{*}{ Food industry } & Food supplement & Promotion of absorption of bioavailable minerals, such as $\mathrm{Ca}^{2+}$ & {$[68]$} \\
\hline & Texture enhancer & Enhancing the rheological and thermal properties, and reducing the hardness of wheat bread & [98] \\
\hline & Oil-reducing agent & Reducing oil uptake during deep-fat frying & [99] \\
\hline & Cryoprotectant & The $y$-PGA with 20 kDa could have higher antifreeze activities than high antifreeze agents like glucose & {$[11]$} \\
\hline & Thickener & Enhancing viscosity for fruit juice beverage, sports drinks & {$[1]$} \\
\hline & Animal feed additives & Increasing egg-shells strength; decreasing body fat, etc & {$[1]$} \\
\hline \multirow[t]{5}{*}{ Medicine } & Metal chelator & Removal of heavy metals and radionuclides & {$[100]$} \\
\hline & Drug carrier/deliverer & Improvement of anticancer; nanoparticle medicine & {$[101]$} \\
\hline & Gene vectors & Use for gene therapy & {$[102]$} \\
\hline & Tissue engineering & $\begin{array}{l}\text { Possessing the better mechanical properties, such as easily removed, the more hydrophilic and } \\
\text { cytocompatible }\end{array}$ & {$[103]$} \\
\hline & Biological adhesive & Substitutes of fibrin with the better lung adhesion and air-leak sealing & {$[104]$} \\
\hline \multirow[t]{3}{*}{ Bioremediation } & Biopolymer flocculant & Substitution for petro-chemically synthesized flocculants, such as polyacrylamide & {$[70]$} \\
\hline & Metal chelates & Removal of heavy metals and radionuclides & [105] \\
\hline & Dye removal & Effectively and circularly removing basic dyes from aqueous solution & {$[71]$} \\
\hline \multirow[t]{6}{*}{ Others } & Moisturizer & Improving the qualities of skincare and hair care products & {$[72]$} \\
\hline & Biocontrol agent & Increasing the nutrient consumption as well as growth of seedlings & {$[106]$} \\
\hline & Biodegradable plastic & Use in biodegradable plastics with good thermoplastic property & {$[7]$} \\
\hline & Antibacterial activity & Its derivatives have antibacterial activity against Salmonella enteritidis, E. coli and Staphylococcus aureus & {$[107]$} \\
\hline & Functional membranes & Separation of metal ions; enantioselection of amino acids & {$[77]$} \\
\hline & Protective effect & Y-PGA has a unique protective effect on phage particles & [108] \\
\hline
\end{tabular}

\section{Wastewater treatment}

Due to its non-toxic and biodegradable properties, $\gamma$-PGA offers an eco-friendly alternative for wastewater treatment. $\gamma$-PGA with a molecular weight of $\sim 5.8-$ $6.2 \times 10^{6} \mathrm{Da}$ appears to be superior to many conventional flocculants used in wastewater treatment plants operating downstream of food processing fermentation processes [70]. More interestingly, $\gamma$-PGA with a molecular weight of $9.9 \times 10^{5}$ Da could effectively remove $98 \%$ of basic dyes from aqueous solution at $\mathrm{pH} 1$ and could then be re-used [71].

\section{Other applications}

$\gamma$-PGA has also been explored for use in cosmetics as a hydrophilic humectant to increase the production of natural moisturizing agents such as urocanic acid, pyrrolidone carboxylic acid, and lactic acid [72]. Many other applications of $\gamma$-PGA likely remain to be discovered.

\section{Conclusion}

During more than 70 years of $\gamma$-PGA-related research, great insight has been gained regarding its production, metabolic regulation, and applications. Owing to its biodegradability and non-toxic and non-immunogenic properties, it is used widely in the food, medicine, and wastewater industries. Biotechnological production of natural $\gamma$-PGA from renewable biomass continues to be of significant interest, especially in the face of decreasing fossil fuels and a need to reduce carbon emissions.

A lot of research has been carried out on the molecular biology (genes, enzymes, pathways) of $\gamma$-PGA and its biosynthesis in different organisms, some of which have been applied to improving its production [7, 8, 73]. The insight obtained has been used to manipulate the osmolarity to identify and isolate novel $\gamma$-PGA-producing strains from different sources [74]. Furthermore, genetic engineering of host strains has improved $\gamma$-PGA yields, expanded the substrate spectrum, and enhanced the robustness of organisms to environmental stresses to create efficient production strains $[75,76]$. Advances in molecular biology have therefore helped to optimize $\gamma$-PGA production and expanded the number of uses to which $\gamma$-PGA can be applied.

The specific properties of $\gamma$-PGA determine its applications, and $\gamma$-PGA produced by different bacteria or culture conditions may therefore be suited to different uses. Optimization of the cost of production, molecular mass, and conformational/enantiomeric properties is crucial if the potential of $\gamma$-PGA is to be fully realized [75]. For instance, a greater understanding of the mechanism of passive drug targeting could lead to the rational improvement of PGA-based drug delivery systems [8]. Moreover, genetic engineering strategies such as directed evolution or site-directed mutagenesis could be used to 
modify the biosynthetic machinery and hence $\gamma$-PGA properties [77]. Clearly, much work remains to be done in this commercially important and academically interesting field of research.

With the increasing trend in using biomass as a carbon source for fermentation processes, much research into the biological production of $\gamma$-PGA has aimed at improving the cost-effectiveness and the efficiency of recovery. To realize better industrial production of $\gamma$-PGA from renewable biomass, further effort should be made in this area. For example, high-throughput screening of potential new producers should include thermo- and salt-tolerant bacterial extremophiles [78]. Additionally, waste biomass materials such as rice straw or manure compost from the dairy and pig industries could be exploited to lower the cost of feedstock [50]. Genetic manipulation could also be exploited to develop novel $\gamma$-PGA 'superproducer' strains. Finally, improving downstream $\gamma$-PGA separation processes could be decisive in improving the cost-effectiveness of production.

A greater understanding of the molecular regulatory mechanisms of $\gamma$-PGA biosynthesis and control of stereoisomers would undoubtedly prove valuable. Therefore, a systems approach that combines synthetic biology, metabolic engineering, and traditional fundamental research will likely lead to improved fermentative production of $\gamma$-PGA from renewable biomass.

\section{Additional file}

Additional file 1: Fig. S1. Molecular structure of $\gamma$-PGA (chiral carbons are indicated with asterisks) [80].

\section{Abbreviations}

$\gamma$-PGA: poly- $\gamma$-glutamic acid; $\gamma$-L-PGA: L-glutamic acid residues; $\gamma$-D-PGA: D-glutamic acid residues; $\gamma$-LD-PGA: L- and D-glutamic acid residues; Mw: molecular weight; pgs: polyglutamate synthase; GGT: $\gamma$-glutamyltranspeptidase.

\section{Authors' contributions}

ZTL and YG made contribution to the design of the study, the acquisition of data, the analysis, and interpretation of data and contributed to the manuscript writing. JDL, HQ, and MMZ conceived the study. WZ and SBL conceived and organized the study, helped to draft the manuscript, and revised the manuscript. All the authors read and approved the final manuscript.

\section{Author details \\ ${ }^{1}$ College of Light Industry and Food Engineering, Guangxi University, Nan- ning 530004, China. ${ }^{2}$ National Engineering Research Center for Non-Food Biorefinery, Guangxi Academy of Sciences, Nanning 530004, China. ${ }^{3}$ Col- lege of Bioengineering, Sichuan University of Science and Engineering, Zigong 643000, Sichuan, China.}

\section{Acknowledgements}

This research was financially supported by the Fund of Guangxi Academy of Sciences (15YJ22SW05), the "Bagui Scholars Distinguished Professor" Special Project, and the Talents introduction program of Sichuan University of Science and Engineering (No. 2013RC12).

\section{Competing interests}

The authors declare that they have no competing interests.

\section{Consent for publication}

All authors agreed to publish this article.

\section{Funding}

Guangxi Academy of Sciences (15YJ22SW05), the "Bagui Scholars Distinguished Professor" Special Project, and the Talents introduction program of Sichuan University of Science and Engineering (No. 2013RC12).

Received: 14 March 2016 Accepted: 31 May 2016

Published online: 29 June 2016

References

1. Shih IL, Van YT. The production of poly-(gamma-glutamic acid) from microorganisms and its various applications. Bioresour Technol. 2001;79:207-25.

2. Sanda F, Fujiyama T, Endo T. Chemical synthesis of poly-gammaglutamic acid by polycondensation of gamma-glutamic acid dimer: synthesis and reaction of poly-gamma-glutamic acid methyl ester. J Polym Sci Polym Chem. 2001;39:732-41.

3. Candela T, Moya M, Haustant M, Fouet A. Fusobacterium nucleatum, the first gram-negative bacterium demonstrated to produce polyglutamate. Can J Microbiol. 2009;55:627-32.

4. Hezayen FF, Rehm BH, Tindall BJ, Steinbuchel A. Transfer of Natrialba asiatica B1T to Natrialba taiwanensis sp. nov. and description of Natrialba aegyptiaca sp. nov., a novel extremely halophilic, aerobic, non-pigmented member of the Archaea from Egypt that produces extracellular poly(glutamic acid). Int J Syst Evol Microbiol. 2001;51:1133-42.

5. Akagi T, Baba M, Akashi M. Preparation of nanoparticles by the selforganization of polymers consisting of hydrophobic and hydrophilic segments: potential applications. Polymer. 2007;48:6729-47.

6. Candela T, Fouet A. Poly-gamma-glutamate in bacteria. Mol Microbiol. 2006;60:1091-8.

7. Ogunleye A, et al. Poly- $\gamma$-glutamic acid: production, properties and applications. Microbiology. 2015;161:1-17.

8. Buescher JM, Margaritis A. Microbial biosynthesis of polyglutamic acid biopolymer and applications in the biopharmaceutical, biomedical and food industries. Crit Rev Biotechnol. 2007;27:1-19.

9. Bajaj I, Singhal R. Poly (glutamic acid) —an emerging biopolymer of commercial interest. Bioresour Technol. 2011;102:5551-61.

10. Ho GH, et al. $\mathrm{Y}$-Polyglutamic acid produced by Bacillus subtilis (natto): structural characteristics, chemical properties and biological functionalities. J Chin Chem Soc. 2006;53:1363-84.

11. Bhat AR, et al. Bacillus subtilis natto: a non-toxic source of poly- $\gamma$ glutamic acid that could be used as a cryoprotectant for probiotic bacteria. AMB Express. 2013;3:36.

12. Shih IL, Van YT, Sau YY. Antifreeze activities of poly(gammaglutamic acid) produced by Bacillus licheniformis. Biotechnol Lett. 2003;25:1709-12.

13. Perez-Camero G, Congregado F, Bou JJ, Munoz-Guerra S. Biosynthesis and ultrasonic degradation of bacterial poly(gamma-glutamic acid). Biotechnol Bioeng. 1999;63:110-5.

14. Mesnage S, Tosi-Couture E, Gounon P, Mock M, Fouet A. The capsule and S-layer: two independent and yet compatible macromolecular structures in Bacillus anthracis. J Bacteriol. 1998;180:52-8.

15. Kocianova $\mathrm{S}$, et al. Key role of poly-gamma-DL-glutamic acid in immune evasion and virulence of Staphylococcus epidermidis. J Clin Invest. 2005;115:688-94.

16. MCLean RJ, Beauchemin D, Clapham L, Beveridge TJ. Metal-binding characteristics of the gamma-glutamyl capsular polymer of Bacillus licheniformis ATCC 9945. Appl Environ Microbiol. 1990;56:3671-7.

17. Yan $\mathrm{S}$, et al. Poly- $\gamma$-glutamic acid produced from Bacillus licheniformis CGMCC 2876 as a potential substitute for polyacrylamide in the sugarcane industry. Biotechnol Prog. 2015;31:1287-94.

18. Ko YH, Gross RA. Effects of glucose and glycerol on gammapoly(glutamic acid) formation by Bacillus licheniformis ATCC 9945a. Biotechnol Bioeng. 1998;57:430-7. 
19. Wu Q, Xu H, Xu L, Ouyang P. Biosynthesis of poly (gamma-glutamic acid) in Bacillus subtilis NX-2: regulation of stereochemical composition of poly(gamma-glutamic acid). Process Biochem. 2006;41:1650-5.

20. Ashiuchi $M$, et al. Enzymatic synthesis of high-molecular-mass polygamma-glutamate and regulation of its stereochemistry. Appl Environ Microbiol. 2004;70:4249-55.

21. Ashiuchi M, Soda K, Misono H. Characterization of yrpC gene product of Bacillus subtilis IFO 3336 as glutamate racemase isozyme. Biosci Biotech Biochem. 1999:63:792-8.

22. Kimura K, Tran LSP, Uchida I, Itoh Y. Characterization of Bacillus subtilis gamma-glutamyltransferase and its involvement in the degradation of capsule poly-gamma-glutamate. Microbiology. 2004;150:4115-23.

23. Ashiuchi M, Kuwana E, Komatsu K, Soda K, Misono H. Differences in effects on DNA gyrase activity between two glutamate racemases of Bacillus subtilis, the poly-gamma-glutamate synthesis-linking Glr enzyme and the YrpC (Murl) isozyme. FEMS Microbiol Lett. 2003;223:221-5.

24. Ashiuchi $\mathrm{M}$, et al. Isolation of Bacillus subtilis (chungkookjang), a polygamma-glutamate producer with high genetic competence. Appl Microbiol Biotechnol. 2001;57:764-9.

25. Sung MH, et al. Natural and edible biopolymer poly-gamma-glutamic acid: synthesis, production, and applications. Chem Rec. 2005;5:352-66.

26. Candela T, Fouet A. Bacillus anthracis CapD, belonging to the gammaglutamyltranspeptidase family, is required for the covalent anchoring of capsule to peptidoglycan. Mol Microbiol. 2005;57:717-26.

27. Yamashiro D, Yoshioka M, Ashiuchi M. Bacillus subtilis pgsE (formerly ywtC) stimulates poly- $\gamma$-glutamate production in the presence of Zinc. Biotechnol Bioeng. 2011;108:226-30.

28. Tran LSP, Nagai T, Itoh Y. Divergent structure of the ComQXPA quorumsensing components: molecular basis of strain-specific communication mechanism in Bacillus subtilis. Mol Microbiol. 2000;37:1159-71.

29. Do TH, et al. Mutations suppressing the loss of DegQ function in Bacillus subtilis (natto) poly- - -glutamate synthesis. Appl Environ Microbiol. 2011;77:8249-58.

30. Osera C, Amati G, Calvio C, Galizzi A. SwrAA activates poly-gamma-glutamate synthesis in addition to swarming in Bacillus subtilis. Microbiology. 2009;155:2282-7.

31. Ohsawa T, Tsukahara K, Ogura M. Bacillus subtilis response regulator DegU is a direct activator of pgsB transcription involved in gamma-poly-glutamic acid synthesis. Biosci Biotechnol Biochem. 2009;73:2096-102.

32. Stanley NR, Lazazzera BA. Defining the genetic differences between wild and domestic strains of Bacillus subtilis that affect poly-gammadl-glutamic acid production and biofilm formation. Mol Microbiol. 2005;57:1143-58.

33. Obst M, Steinbuchel A. Microbial degradation of poly(amino acid)s. Biomacromolecules. 2004;5:1166-76.

34. King EC, Blacker AJ, Bugg TDH. Enzymatic breakdown of poly-gammaD-glutamic acid in Bacillus licheniformis: identification of a polyglutamyl gamma-hydrolase enzyme. Biomacromolecules. 2000;1:75-83.

35. Yao J, et al. Investigation on enzymatic degradation of $Y$-polyglutamic acid from Bacillus subtilis NX-2. J Mol Catal B Enzym. 2009;56:158-64.

36. Ashiuchi M, Kamei T, Misono H. Poly-gamma-glutamate synthetase of Bacillus subtilis. J Mol Catal B Enzym. 2003;23:101-6.

37. Xu K, Strauch MA. Identification, sequence, and expression of the gene encoding gamma-glutamyltranspeptidase in Bacillus subtilis. J Bacteriol. 1996;178:4319-22.

38. Candela T, et al. $\mathrm{N}$-acetylglucosamine deacetylases modulate the anchoring of the gamma-glutamyl capsule to the cell wall of Bacillus anthracis. Microb Drug Resist. 2014;20:222-30.

39. Morelli CF, Calvio C, Biagiotti M, Speranza G. pH-dependent hydrolase, glutaminase, transpeptidase and autotranspeptidase activities of Bacillus subtilis Y-glutamyltransferase. FEBS J. 2014;281:232-45.

40. Uchida I, et al. Identification of a novel gene, dep, associated with depolymerization of the capsular polymer in Bacillus anthracis. Mol Microbiol. 1993:9:487-96.

41. Tahara Y. In: United States Patent Application. 2003.

42. Xu ZQ, et al. Enhanced poly(Y-glutamic acid) fermentation by Bacillus subtilis NX-2 immobilized in an aerobic plant fibrous-bed bioreactor. Bioresour Technol. 2014;155:8-14.
43. Zhao CF, et al. Production of ultra-high molecular weight poly-yglutamic acid with Bacillus licheniformis P-104 and characterization of its flocculation properties. Appl Biochem Biotechnol. 2013;170:562-72.

44. Shih IL, Wu PJ, Shieh CJ. Microbial production of a poly (gammaglutamic acid) derivative by Bacillus subtilis. Process Biochem. 2005;40:2827-32.

45. Cao MF, et al. Glutamic acid independent production of poly- $\gamma^{-}$ glutamic acid by Bacillus amyloliquefaciens LL3 and cloning of pgsBCA genes. Bioresour Technol. 2011;102:4251-7.

46. Feng J, et al. Metabolic engineering of Bacillus amyloliquefaciens for poly-gamma-glutamic acid (y-PGA) overproduction. Microb Biotechnol. 2014;7:446-55.

47. Ashiuchi M, Shimanouchi K, Horiuchi T, Kame T, Misono H. Genetically engineered poly-gamma-glutamate producer from Bacillus subtilis ISW1214. Biosci Biotechnol Biochem. 2006;70:1794-7.

48. Cao MF, et al. Engineering of recombinant Escherichia coli cells co-expressing poly- $\gamma$-glutamic acid ( $\gamma$-PGA) synthetase and glutamate racemase for differential yielding of $\gamma$-PGA. Microb Biotechnol. 2013;6:675-84.

49. Huang J, et al. High yield and cost-effective production of poly(gammaglutamic acid) with Bacillus subtilis. Eng Life Sci. 2011;11:291-7.

50. Tang $B$, et al. Highly efficient rice straw utilization for poly-( $(y-$ glutamic acid) production by Bacillus subtilis NX-2. Bioresour Technol. 2015;193:370-6.

51. Peng YY, et al. High-level production of poly(Y-glutamic acid) by a newly isolated glutamate-independent strain, Bacillus methylotrophicus. Process Biochem. 2015;50:329-35.

52. Cachat E, Barker M, Read TD, Priest FG. A Bacillus thuringiensis strain producing a polyglutamate capsule resembling that of Bacillus anthracis. FEMS Microbiol Lett. 2008;285:220-6.

53. Ezzell JW, et al. Association of Bacillus anthracis capsule with lethal toxin during experimental infection. Infect Immun. 2009;77:749-55.

54. Yao W, Meng G, Zhang W, Chen X, Yin R. Vol CN103146630 (A), China. 2013.

55. Zhang $D$, Feng $X H$, Zhou Z, Zhang $Y, X u H$. Economical production of poly $(\gamma$-glutamic acid) using untreated cane molasses and monosodium glutamate waste liquor by Bacillus subtilis NX-2. Bioresour Technol. 2012;114:583-8.

56. Ju WT, Song YS, Jung WJ, Park RD. Enhanced production of poly- $\gamma$ glutamic acid by a newly-isolated Bacillus subtilis. Biotechnol Lett. 2014:36:2319-24.

57. Ji XJ, et al. Elimination of carbon catabolite repression in Klebsiella oxytoca for efficient 2,3-butanediol production from glucose-xylose mixtures. Appl Microbiol Biotechnol. 2011;89:1119-25.

58. Cromwick AM, Birrer GA, Gross RA. Effects of $\mathrm{pH}$ and aeration on gamma-poly (glutamic acid) formation by Bacillus licheniformis in controlled batch fermentor cultures. Biotechnol Bioeng. 1996;50:222-7.

59. Zhang D, Feng XH, Li S, Chen F, Xu H. Effects of oxygen vectors on the synthesis and molecular weight of poly (gamma-glutamic acid) and the metabolic characterization of Bacillus subtilis NX-2. Process Biochem. 2012;47:2103-9.

60. Xu H, Jiang M, Li H, Lu DQ, Ouyang P. Efficient production of poly (gamma-glutamic acid) by newly isolated Bacillus subtilis NX-2. Process Biochem. 2005:40:519-23.

61. Richard A, Margaritis A. Optimization of cell growth and poly(glutamic acid) production in batch fermentation by Bacillus subtilis. Biotechnol Lett. 2003;25:465-8.

62. $\mathrm{Wu} \mathrm{Q}, \mathrm{Xu} \mathrm{H}$, Ying HJ, Ouyang PK. Kinetic analysis and $\mathrm{pH}$-shift control strategy for poly(gamma-glutamic acid) production with Bacillus subtilis CGMCC 0833. Biochem Eng J. 2010;50:24-8.

63. Xu Z, Shi F, Cen P. Production of polyglutamic acid from mixed glucose and sucrose by co-cultivation of Bacillus subtilis and Corynebacterium glutamicum. In: The 2005 AlChE annual meeting, Cincinnati. 2005. https://aiche.confex.com/aiche/2005/techprogram/P25321.HTM. Accessed 24 June 2016.

64. Do JH, Chang HN, Lee SY. Efficient recovery of gamma-poly (glutamic acid) from highly viscous culture broth. Biotechnol Bioeng. 2001;76:219-23.

65. Park C, et al. Synthesis of super-high-molecular-weight poly-gammaglutamic acid by Bacillus subtilis subsp chungkookjang. J Mol Catal B Enzym. 2005;35:128-33. 
66. Yoon SH, Do JH, Lee SY, Chang HN. Production of poly- $\gamma$-glutamic acid by fed-batch culture of Bacillus licheniformis. Biotechnol Lett. 2000;22:585-8.

67. Siaterlis A, Deepika G, Charalampopoulos D. Effect of culture medium and cryoprotectants on the growth and survival of probiotic lactobacilli during freeze drying. Lett Appl Microbiol. 2009;48:295-301.

68. Tanimoto $\mathrm{H}$, et al. Acute effect of poly-gamma-glutamic acid on calcium absorption in post-menopausal women. J Am Coll Nutr. 2007:26:645-9.

69. Singer JW. Paclitaxel poliglumex (XYOTAX (TM), CT-2103): a macromolecular taxane. J Control Release. 2005;109:120-6.

70. Bajaj IB, Singhal RS. Flocculation properties of poly(gamma-glutamic acid) produced from Bacillus subtilis isolate. Food Bioprocess Tech. 2011:4:745-52.

71. Inbaraj BS, Chiu CP, Ho GH, Yang J, Chen BH. Removal of cationic dyes from aqueous solution using an anionic poly-gamma-glutamic acidbased adsorbent. J Hazard Mater. 2006;137:226-34.

72. Ben-Zur N, Goldman DM. Y-Poly glutamic acid: a novel peptide for skin care. Cosmet Toilet. 2007;122:65-74.

73. Ashiuchi M, Misono H. Biochemistry and molecular genetics of polygamma-glutamate synthesis. Appl Microbiol Biotechnol. 2002;59:9-14.

74. Zeng W, et al. An integrated high-throughput strategy for rapid screening of poly(gamma-glutamic acid)-producing bacteria. Appl Microbiol Biotechnol. 2013;97:2163-72.

75. Jiang $F$, et al. Expression of glr gene encoding glutamate racemase in Bacillus licheniformis WX-02 and its regulatory effects on synthesis of poly-gamma-glutamic acid. Biotechnol Lett. 2011;33:1837-40.

76. Jiang H, Shang L, Yoon SH, Lee SY, Yu Z. Optimal production of polygamma-glutamic acid by metabolically engineered Escherichia coli. Biotechnol Lett. 2006;28:1241-6.

77. Ashiuchi M. Microbial production and chemical transformation of polyy-glutamate. Microb Biotechnol. 2013;6:664-74.

78. Wei XT, Tian GM, Ji ZX, Chen SW. A new strategy for enhancement of poly-gamma-glutamic acid production by multiple physicochemical stresses in Bacillus licheniformis. J Chem Technol Biotechnol. 2015;90:709-13.

79. Peng Y, Zhang T, Mu W, Miao M, Jiang B. Intracellular synthesis of glutamic acid in Bacillus methylotrophicus SK19.001, a glutamateindependent poly( $\gamma$-glutamic acid)-producing strain. J Sci Food Agric. 2016;96:66-72.

80. Zhu F, et al. The main byproducts and metabolic flux profiling of gamma-PGA-producing strain B. subtilis ZJU-7 under different $\mathrm{pH}$ values. J Biotechnol. 2013;164:67-74.

81. Bajaj IB, Singhal RS. Enhanced production of poly (gamma-glutamic acid) from Bacillus licheniformis NCIM 2324 by using metabolic precursors. Appl Biochem Biotechnol. 2009;159:133-41.

82. Zhu F, et al. A novel approach for poly-gamma-glutamic acid production using xylose and corncob fibres hydrolysate in Bacillus subtillis HB-1. J Chem Technol Biotechnol. 2014;89:616-22.

83. Kongklom N, et al. Production of poly-gamma-glutamic acid by glutamic acid-independent Bacillus licheniformis TISTR 1010 using different feeding strategies. Biochem Eng J. 2015;100:67-75.

84. Feng J, et al. Functions of poly-gamma-glutamic acid (gamma-PGA) degradation genes in gamma-PGA synthesis and cell morphology maintenance. Appl Microbiol Biotechnol. 2014;98:6397-407.

85. Zhang W, et al. Deletion of genes involved in glutamate metabolism to improve poly-gamma-glutamic acid production in Bacillus amyloliquefaciens LL3. J Ind Microbiol Biotechnol. 2015;42:297-305.

86. Feng J, et al. Improved poly- $\gamma$-glutamic acid production in Bacillus amyloliquefaciens by modular pathway engineering. Metab Eng. 2015;32:106-15

87. Scoffone $V$, et al. Knockout of pgdS and ggt genes improves gammaPGA yield in B. subtilis. Biotechnol Bioeng. 2013;110:2006-12.

88. Tian $\mathrm{G}$, et al. Enhanced expression of pgdS gene for high production of poly- $\gamma$-glutamic acid with lower molecular weight in Bacillus licheniformis WX-02. J Chem Technol Biotechnol. 2014;89:1825-32.
89. Bajaj IB, Lele SS, Singhal RS. A statistical approach to optimization of fermentative production of poly (gamma-glutamic acid) from Bacillus licheniformis NCIM 2324. Bioresour Technol. 2009;100:826-32.

90. Zhang D, et al. Improvement of poly (gamma-glutamic acid) biosynthesis and quantitative metabolic flux analysis of a two-stage strategy for agitation speed control in the culture of Bacillus subtilis NX-2. Biotechnol Bioprocess Eng. 2011;16:1144-51.

91. de Cesaro A, da Silva SB, Ayub MAZ. Effects of metabolic pathway precursors and polydimethylsiloxane (PDMS) on poly-(gamma)-glutamic acid production by Bacillus subtilis BL53. J Ind Microbiol Biotechnol. 2014:41:1375-82.

92. Zhang $\mathrm{H}$, et al. High-level exogenous glutamic acid-independent production of poly-(gamma-glutamic acid) with organic acid addition in a new isolated Bacillus subtilis C10. Bioresour Technol. 2012;116:241-6.

93. Zeng $W$, et al. Non-sterilized fermentative co-production of poly(gamma-glutamic acid) and fibrinolytic enzyme by a thermophilic Bacillus subtilis GXA-28. Bioresour Technol. 2013;142:697-700.

94. Yong $X Y$, et al. Optimization of the production of poly-gamma-glutamic acid by Bacillus amyloliquefaciens $\mathrm{C} 1$ in solid-state fermentation using dairy manure compost and monosodium glutamate production residues as basic substrates. Bioresour Technol. 2011;102:7548-54.

95. Zeng $W$, et al. Regulation of poly- $\gamma$-glutamic acid production in Bacillus subtilis GXA-28 by potassium. J Taiwan Inst Chem Engineers. 2016;61:83-9.

96. Wang J, Yuan H, Wei X, Chen J, Chen S. Enhancement of poly- $\gamma^{-}$ glutamic acid production by alkaline $\mathrm{pH}$ stress treatment in Bacillus licheniformis WX-02. J Chem Technol Biotechnol. n/a-n/a. 2015.

97. Tang B. et al. Enhanced poly( $\gamma$-glutamic acid) production by $\mathrm{H}_{2} \mathrm{O} 2-$ induced reactive oxygen species in the fermentation of Bacillus subtilis NX-2. Biotechnol Appl Biochem. n/a-n/a. 2015.

98. Shyu YS, Sung WC. Improving the emulsion stability of sponge cake by the addition of gamma-polyglutamic acid. J Mar Sci Technol. 2010;18:895-900.

99. Lim SM, et al. Effect of poly-gamma-glutamic acids (pga) on oil uptake and sensory quality in doughnuts. Food Sci Biotechnol. 2012;21:247-52.

100. Inbaraj BS, Chen BH. In vitro removal of toxic heavy metals by poly(gamma-glutamic acid)-coated superparamagnetic nanoparticles. Int J Nanomedicine. 2012;7:4419-32.

101. Ye HF, et al. Poly(gamma, L-glutamic acid)-cisplatin conjugate effectively inhibits human breast tumor xenografted in nude mice. Biomaterials. 2006;27:5958-65.

102. Kurosaki T, et al. Ternary complexes of pDNA, polyethylenimine, and gamma-polyglutamic acid for gene delivery systems. Biomaterials. 2009;30:2846-53.

103. Tsao CT, et al. Evaluation of chitosan/gamma-poly(glutamic acid) polyelectrolyte complex for wound dressing materials. Carbohydr Polym. 2011;84:812-9.

104. Otani Y, Tabata Y, Ikada Y. Sealing effect of rapidly curable gelatin-poly (L-glutamic acid) hydrogel glue on lung air leak. Ann Thorac Surg. 1999:67:922-6.

105. Bhattacharyya D, et al. Novel poly-glutamic acid functionalized microfiltration membranes for sorption of heavy metals at high capacity. J Membr Sci. 1998;141:121-35.

106. Wang QJ, et al. Co-producing lipopeptides and poly-gamma-glutamic acid by solid-state fermentation of Bacillus subtilis using soybean and sweet potato residues and its biocontrol and fertilizer synergistic effects. Bioresour Technol. 2008;99:3318-23.

107. Inbaraj BS, et al. The synthesis and characterization of poly $(\gamma$-glutamic acid)-coated magnetite nanoparticles and their effects on antibacterial activity and cytotoxicity. Nanotechnology. 2011;22:075101.

108. Khalil l, et al. Poly- $\gamma$-glutamic acid: biodegradable polymer for potential protection of beneficial viruses. Materials. 2016;9:28. 